\title{
Model Optimisasi Distribusi dan Perencanaan Terminal Regasifikasi Liquefied Natural Gas (LNG) Studi Kasus Pulau Jawa
}

\author{
Riza Alfian Arif Wardana, I Gusti Ngurah Sumanta Buana, dan Hasan Iqbal Nur \\ Departemen Teknik Transportasi Laut, Institut Teknologi Sepuluh Nopember (ITS) \\ e-mail: hasaniqbal@seatrans.its.ac.id
}

\begin{abstract}
Abstrak-Biaya pengapalan LNG yang tinggi mengakibatkan tingginya harga gas yang digunakan sebagai bahan bakar pembangkit listrik. Selain itu, pembangunan unit pembangkitan baru di Cilamaya dan peningkatan kapasitas daya UP Grati mengakibatkan peningkatan permintaan akan LNG. Perencanaan terminal regasifikasi di Jawa Timur diharapkan dapat menunjang pemenuhan kebutuhan akan LNG di UP Gresik dan Grati. Penyedia sarana pembangkit tenaga mengharapkan biaya LNG di Unit Pembangkitan lebih rendah dari nilai 14,5\% Indonesian Crude Price (ICP). Permasalahan tersebut akan diselesaikan dengan model optimisasi pendistribusian LNG yang berasal dari 3 (tiga) kilang produksi, yaitu Badak LNG, Donggi Senoro LNG dan Tangguh LNG menuju 3 (tiga) terminal penerima LNG di Jawa. Model optimisasi tersebut menghasilkan 4 pilihan kapal yang digunakan dengan biaya total sebesar Rp34.620.155.621.573 untuk memenuhi permintaan akan LNG yang berjumlah $16.244 .803 \mathrm{~m}^{3}$ dan biaya satuan LNG $\$ 7,53 / M B T U$. Perencanaan terminal regasifikasi yang dilakukan menghasilkan dua unit tangki penyimpanan berkapasitas 75.000 $\mathbf{m}^{3}$ dan biaya per tahun sebesar Rp561.191.198.608.
\end{abstract}

Kata Kunci-Model Optimisasi, Distribusi LNG, Terminal Regasifikasi.

\section{PENDAHULUAN}

$\mathrm{P}$ EMBANGKIT Listrik Tenaga Gas (PLTG) di Indonesia, yang sebagian besar terletak di Pulau Jawa, yaitu memiliki kapasitas daya sebesar $75 \%$ dari kapasitas daya total Indonesia. Pemerintah berencana untuk memusatkan pasokan listrik di Pulau Jawa untuk kebutuhan listrik masyarakat yang disuplai oleh beberapa PLTG yang terdapat di Jawa, yaitu Unit Pembangkitan (UP) Gresik, Grati di Pasuruan, Muara Tawar di Bekasi, dan Muara Karang di Jakarta. Pemerintah telah meresmikan pembangunan Pembangkit Listrik Tenaga Gas dan Uap (PLTGU) dengan kapasitas 1.760 MW di Cilamaya, Karawang, Jawa Barat pada tahun 2019. Pembangkit yang dibangun diharapkan bisa menambah pasokan listrik untuk 11 juta pelanggan. Selain pembangunan tersebut, PLTGU di Grati, Pasuruan melakukan penambahan kapasitas daya $500 \mathrm{MW}$. Peningkatan kapasitas daya PLTG di Jawa tersebut mengakibatkan peningkatan kebutuhan akan gas alam, sehingga pemerintah berupaya untuk melakukan pemebuhan kebutuhan gas domestik, terutama di Pulau Jawa. Biaya pengapalan atau pengiriman LNG di Indonesia dapat dikatakan relatif tinggi dan tidak mempunyai jangkauan biaya yang pasti, sebagai contoh: biaya pengapalan LNG dari Badak LNG di Bontang menuju Benoa di Bali sebesar US\$ 1,9/MMBTU, biaya tersebut belum ditambah dengan biaya regasifikasi dan distribusi lewat pipa gas dengan panjang 5 KM. Sebagai

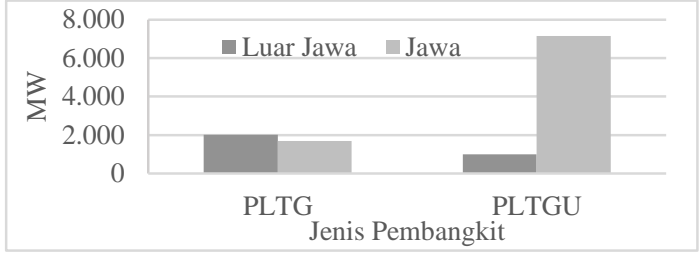

Gambar 1 Pembangkit Listrik Tenaga Gas di Indonesia.

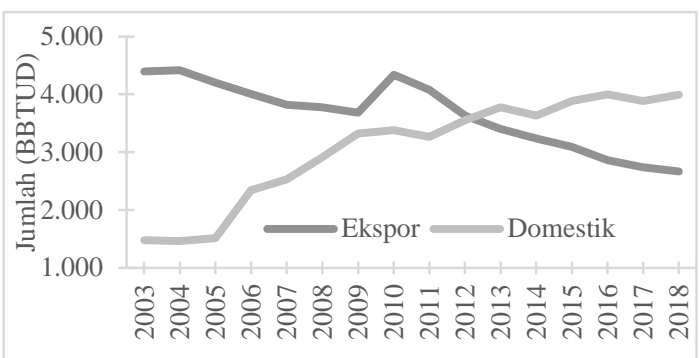

Gambar 2 Pemenuhan Kebutuhan Gas Domestik dan Ekspor Indonesia

pembanding, biaya pengapalan LNG dari Tangguh LNG di Papua Barat ke Terminal Penerimaan dan Regasifikasi LNG Arun di Aceh hanya US\$ 0,08/MMBTU. Biaya pengapalan LNG dari Badak LNG di Bontang menuju Benoa di Bali memiliki nilai yang lebih besar apabila dibandingkan dengan LNG untuk Arun yang dikirim dari Papua Barat, yang memiliki jarak 2,5 kali lipat lebih jauh dari Bontang - Tanjung Benoa. LNG yang dipasok diharapkan dapat memenuhi kebutuhan akan gas pembangunan pembangkit baru, penambahan jumlah kapasitas, dan usulan oleh PLN. LNG yang dipasok diharapkan dapat memenuhi kebutuhan dan terdistribusi dengan biaya yang minimum. Pendistribusian LNG juga harus didukung dengan adanya terminal regasifikasi yang berfungsi sebagai fasilitas yang mengkonversi kembali menjadi gas alam.

\section{METODOLOGI PENELITIAN}

\section{A. Metode Pengumpulan Data}

Pengumpulan data tidak langsung (sekunder) diperoleh dari lembaga yang mempublikasikan data pada sistem digital seperti website yang dimiliki perusahaan terkait, Kementerian, Badan Pusat Statistik, serta artikel, jurnal, dan studi literatur.

\section{B. Tahap Identifikasi Kondisi Terkini}

Tahap identifikasi merupakan penjelasan mengenai kondisi terkini dari distribusi LNG di Pulau Jawa. Adapun beberapa tahapan identifikasi adalah sebagai berikut:

1) Identifikasi distribusi LNG di Pulau Jawa 


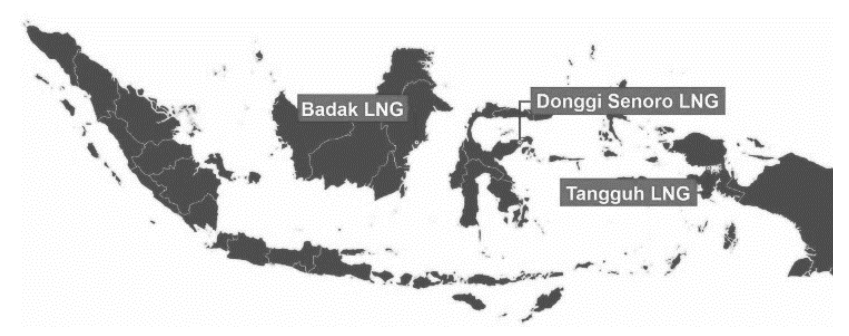

Gambar 5. Lokasi Kilang Pemasok LNG.

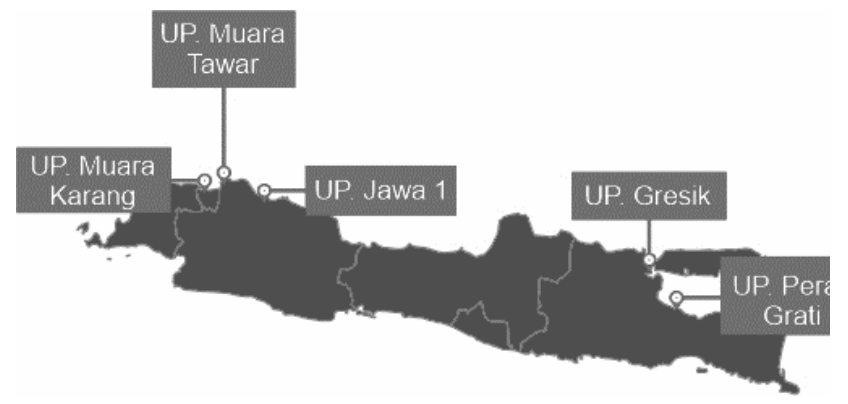

Gambar 6. Lokasi Unit Pembangkitan Listrik Tenaga Gas di Jawa.

2) Identifikasi pasokan dan permintaan $\mathrm{LNG}$

3) Identifikasi biaya distribusi LNG

\section{Tahap Analisis}

Analisis dan pengolahan data dilakukan sesuai dengan rumusan masalah yang sudah ditentukan dan data yang dikumpulkan. Analisis dan pengolahan data tersebut mengenai jumlah pasokan di kilang produksi yang ditujukan untuk pemenuhan kebutuhan bahan bakar gas di Pulau Jawa, permintaan LNG oleh PLTG, armada kapal pengangkut gas yang digunakan, jaringan pipa gas di darat, dan biaya distribusi LNG dari kilang produksi menuju Pulau Jawa.

Analisis pertama yang dilakukan adalah mengetahui jumlah pasokan LNG di Pulau Jawa, yang didapatkan dari data proyeksi pemenuhan kebutuhan gas domestik dan persentase kapasitas daya PLTG di Jawa terhadap kapasitas daya total di Indonesia, yang kemudian dilanjutkan dengan analisis kebutuhan akan gas alam sebagai bahan bakar pembangkit listrik tenaga gas di Pulau Jawa.

Analisis selanjutnya adalah menentukan moda transportasi darat dan laut beserta komponen biayanya. Setelah melakukan analisis tersebut, dilakukan perumusan model optimisasi. Metode optimisasi dirumuskan guna mendapatkan distribusi LNG di Pulau Jawa dengan biaya total yang minimum. Model optimisasi terdiri dari 3 (tiga) komponen utama, yaitu objective function, decision variable dan constrain [1]. Model optimisasi distribusi LNG di Pulau Jawa dirumuskan sebagai berikut:

a. Objective function $(\mathrm{OF})$

Minimum $Z=$ Minimum Biaya Total

Biaya Total $=$ Biaya Tetap + Biaya Variabel

Biaya Tetap $=$ Biaya Sewa Kapal + Biaya Pipa Gas

$$
=\left(\sum_{i=1}^{n} F_{i} y_{i}+\sum_{i=n+1}^{e} P_{i} y_{i}\right)
$$

Biaya Variabel $=$ Biaya BBM + Biaya Kepelabuhanan +

Biaya Regasifikasi + Biaya $L N G$

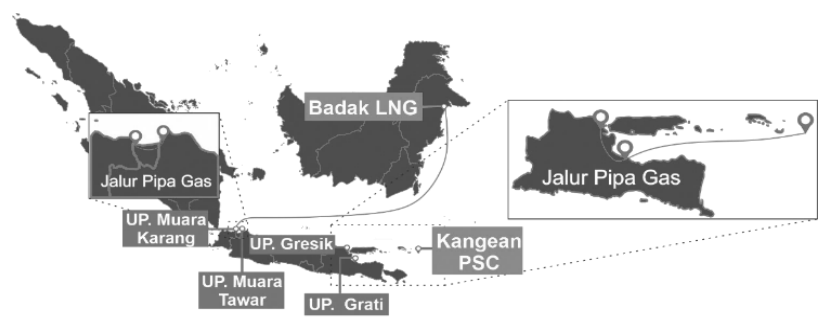

Gambar 3. Distribusi LNG di Pulau Jawa Saat Ini.

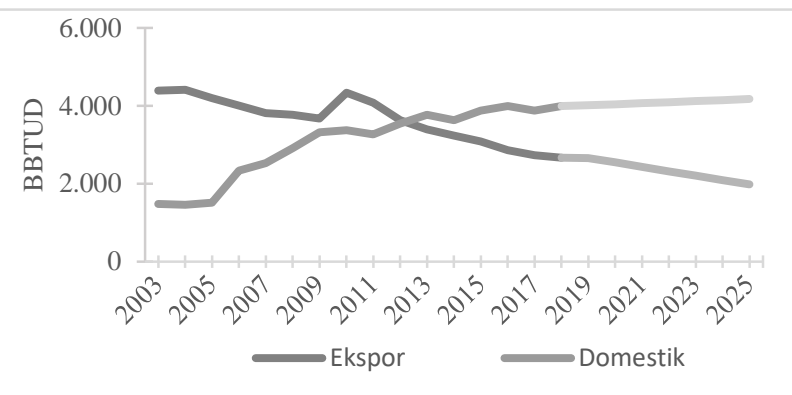

Gambar 4. Proyeksi Pemenuhan Kebutuhan Gas.

$=\left(\begin{array}{c}\sum_{i=1}^{n} \sum_{j=1}^{m} b_{i j}\left(x_{i j} / p_{i}\right)+\sum_{i=1}^{n} \sum_{j=1}^{m} l_{i j}\left(x_{i j} / p_{i}\right)+\sum_{i=1}^{n} \sum_{j=1}^{m} \sum_{k=1}^{o} x_{i j k} c_{k}+ \\ \sum_{i=1}^{n} \sum_{j=1}^{m} \sum_{t=1}^{q}\left(x_{i j}-p_{i} b g\left(x_{i j} / p_{i}\right) w_{i j}\right) r_{t}\end{array}\right)$

Keterangan:

Z : Total Biaya (Rp)

Biaya Tetap : Biaya Charter Kapal + Biaya Operasi Jaringan Pipa

Biaya Variabel : Biaya BBM + Biaya Kepelabuhanan + Biaya Regasifikasi + Biaya LNG

$F_{i} \quad$ : Biaya tetap alterantif kapal $i$

$y_{i} \quad:$ Pemilihan kapal/pipa gas iuntuk $y_{i} \in\{0,1\}$

$P_{i} \quad$ : Biaya jaringan pipa gas $i$

$i \quad:$ Alternatif kapal untuk $i=1, \ldots, n$

$i \quad$ : Jaringan pipa gas untuk $i=\mathrm{n}+1, \ldots, e$

$j \quad:$ Rute pelayaran untuk $j=1, \ldots, m$

$b_{i j} \quad$ : Biaya konsumsi bahan baka kapal $i$ pada rute $j$

$x_{i j} \quad$ : Jumlah LNG yang diangkut kapal $i$ pada rute $j$

$p_{i} \quad$ : Payload kapal $i$

$l_{i j} \quad$ : Biaya kepelabuhanan kapal $i$ pada rute $j$

$c_{k} \quad$ : Biaya LNG pada kilang $k$

$k \quad:$ Kilang produksi LNG untuk $\mathrm{k}=1, \ldots, o$

$x_{i j k} \quad$ : Jumlah LNG yang diangkut kapal $i$ pada rute $j$ yang berasal dari kilang $k$

bg : Faktor boill-off gas

$w_{i j} \quad$ : Waktu round trip kapal $i$ pada rute $j$

$r_{t} \quad$ : Biaya regasifikasi LNG pada terminal $t$

$t \quad$ : Terminal penerima untuk $\mathrm{t}=1, \ldots, q$

b. Decision variable (DV)

Keterangan:

$$
x_{i j}
$$

$x_{i j} \quad$ : Jumlah muatan yang diangkut kapal $i$ pada rute $j$

c. Constraint

$$
x_{i j} \geq 0
$$




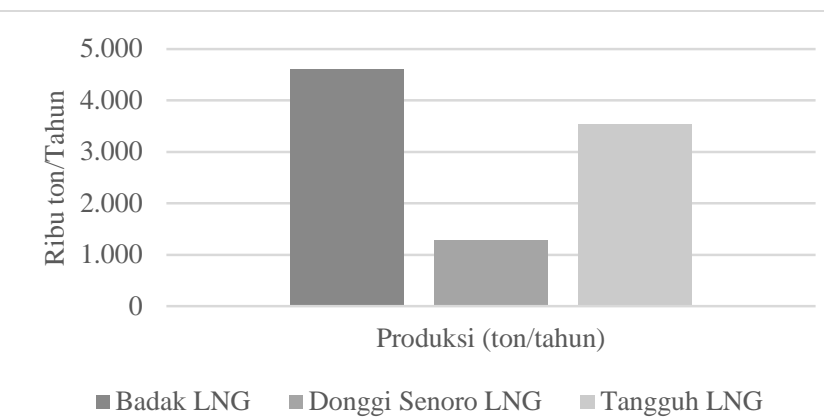

Gambar 8. Pasokan LNG untuk Pulau Jawa di Setiap Kilang.

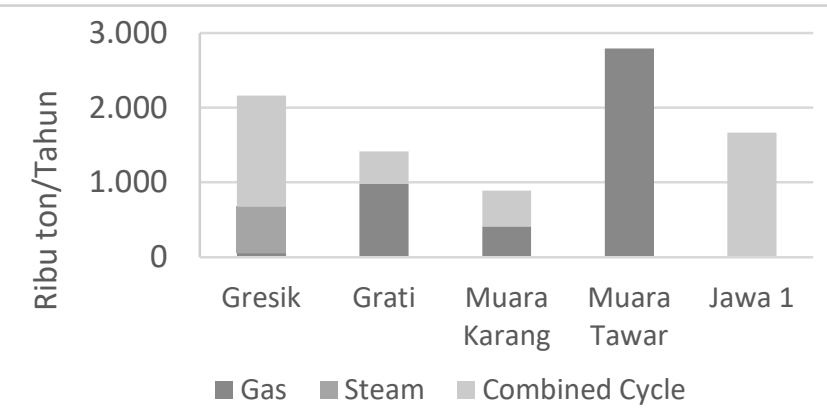

Gambar 9. Kebutuhan Gas di Setiap Unit Pembangkitan.

$$
\begin{aligned}
& \sum_{i=1}^{n} \sum_{j=1}^{m}\left(x_{i j} / p_{i}\right) w_{i j} \leq 330 \\
& \sum_{i=1}^{n} \sum_{j=1}^{m} x_{i j} \leq \sum_{k=1}^{o} S_{k} \\
& \sum_{i=1}^{n} \sum_{j=1}^{m}\left(x_{i j}-p_{i} b g\left(x_{i j} / p_{i}\right) w_{i j}\right) \geq \sum_{t=1}^{q} D_{t}
\end{aligned}
$$

Keterangan:

\section{GAMBARAN UMUM}

\section{A. Pembangkit Listrik Tenaga Gas di Indonesia}

Pembangkit listrik tenaga gas di Indonesia tidak hanya berada di Pulau Jawa saja, tetapi juga terdapat di Luar Jawa. Wilayah yang memiliki pembangkit listrik tenaga gas di Indonesia dibagi menjadi dua wilayah, yaitu Jawa dan Luar Jawa. Terdapat dua jenis pembangkit listrik tenaga gas, yaitu PLTG dan PLTGU. PLTG hanya menggunakan mesin turbin gas, sedangkan PLTGU menggunakan mesin dengan langkah gabungan, yang menggabungkan penggunaan bahan bakar gas dan uap yang dihasilkan dari pembakaran bahan bakar gas tersebut.

Daya pembangkit listrik tenaga gas di Jawa sebesar 8.834,54 MW dan di Luar Jawa sebesar 3.012,65 MW. Daya PLTG di Luar Jawa lebih besar daripada di Jawa, sedangkan daya

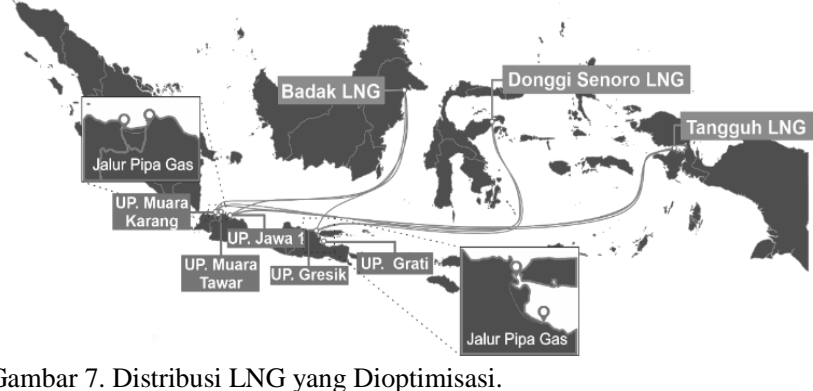

Tabel 1.

Rute Optimisasi Distribusi LNG

\begin{tabular}{llll}
\hline \multicolumn{3}{l}{ Transportasi Laut } & \\
No. & Asal & Tujuan & $\begin{array}{l}\text { Jarak } \\
\text { (NM) }\end{array}$ \\
\hline 1 & Bontang & Muara Karang & 863 \\
2 & Bontang & Cilamaya & 830 \\
3 & Bontang & Gresik & 571 \\
4 & Donggi & Muara Karang & 1.300 \\
5 & Donggi & Cilamaya & 1.260 \\
6 & Donggi & Gresik & 862 \\
7 & Bintuni & Muara Karang & 1.633 \\
8 & Bintuni & Cilamaya & 1.595 \\
9 & Bintuni & Gresik & 1.290 \\
Transportasi Darat (Pipa Gas) & \\
No. & Asal & Tujuan & Jarak \\
1 & Muara Karang & Muara Tawar & 27 \\
2 & Gresik & Grati & 98 \\
\hline
\end{tabular}

PLTGU di Jawa lebih besar daripada di Luar Jawa. Persentase daya pembangkit listrik tenaga gas di Jawa sebesar 75\%, sedangkan di Luar Jawa sebesar 25\% dari kapasitas daya total pembangkit listrik tenaga gas di Indonesia. Persentase daya tersebut akan digunakan sebagai proporsi jumlah produksi LNG di masing-masing kilang yang ditujukan sebagai pasokan untuk pembangkit listrik tenaga gas yang terdapat di Pulau Jawa [2]. (Gambar 1)

\section{B. Pemenuhan Kebutuhan Gas Indonesia}

Kilang produksi LNG di Indonesia melakukan pemenuhan terhadap kebutuhan gas domestik maupun ekspor. Kebutuhan gas domestik adalah permintaan akan gas sebagai bahan bakar pembangkit listrik maupun untuk kebutuhan industri, sedangkan kebutuhan gas ekspor adalah permintaan akan gas oleh negara lain, khususnya negara-negara di wilayah Asia.

Jumlah gas yang diekspor oleh Indonesia pada 2003 jauh lebih besar daripada pasokan gas untuk pemenuhan kebutuhan gas domestik, dengan persentase produksi gas sebesar $75 \%$ untuk ekspor dan $25 \%$ untuk kebutuhan domestik. Pasokan gas untuk pemenuhan gas domestik pada 2013 lebih besar daripada ekspor ke luar negeri, hingga pada 2018 persentase pasokan gas untuk pemenuhan kebutuhan domestik mencapai $60 \%$ dari total produksi gas di Indonesia (Gambar 2). Hal ini menunjukkan bahwa produksi gas di Indonesia diprioritaskan untuk memenuhi kebutuhan gas domestik. Pemenuhan kebutuhan gas tersebut akan diproyeksi hingga 2025 dan dijadikan sebagai acuan pembagian produksi LNG yang akan digunakan sebagai pasokan untuk pemenuhan kebutuhan gas domestik [3].

\section{Kilang Pemasok $L N G$}

Kilang pemasok juga dapat disebut juga dengan export terminal/liquefaction terminal, karena memiliki fasilitas 
Tabel 2.

Alternatif Kapal yang Akan Digunakan

\begin{tabular}{lllll}
\hline Kapal & GT & DWT(ton) & $\begin{array}{l}\text { Payload } \\
\left(\mathrm{m}^{3}\right)\end{array}$ & $\begin{array}{l}\text { Kecepatan } \\
(\text { Knot })\end{array}$ \\
\hline A & 85.616 & 71.472 & 116.954 & 15 \\
B & 93.750 & 79.950 & 130.827 & 17 \\
C & 86.205 & 73.519 & 120.304 & 16 \\
D & 94.446 & 76.197 & 124.686 & 17 \\
E & 106.771 & 89.766 & 146.890 & 16 \\
F & 106.151 & 67.554 & 110.543 & 17 \\
\hline
\end{tabular}

Tabel 3.

Hasil Perhitungan Model Optimisasi Distribusi LNG

\begin{tabular}{|c|c|}
\hline Keterangan & $\begin{array}{l}4 \text { Kapal } \\
\text { B, C, D, dan F }\end{array}$ \\
\hline Biaya total (Rp) & 34.620 .155 .621 .573 \\
\hline Biaya pengapalan $(\mathrm{Rp})$ & 3.043 .928 .023 .655 \\
\hline Biaya pipa gas (Rp) & 717.322 .364 .861 \\
\hline Muatan terangkut $\left(\mathrm{m}^{3}\right)$ & 16.342 .675 \\
\hline Boil-off gas $\left(\mathrm{m}^{3}\right)$ & 97.871 \\
\hline Muatan terkirim $\left(\mathrm{m}^{3}\right)$ & 16.244 .803 \\
\hline Biaya LNG (Rp) & 27.203 .694 .533 .030 \\
\hline Biaya regasifikasi (Rp) & 3.655 .210 .700 .026 \\
\hline Biaya satuan (\$/MBTU) & 7,53 \\
\hline $\begin{array}{l}\text { Waktu operasi rata-rata } \\
\text { (hari/tahun) }\end{array}$ & 252 \\
\hline
\end{tabular}

liquifaksi gas dan berfungsi sebagai terminal muat LNG yang akan dikirimkan ke terminal penerima atau terminal regasifikasi.

Terdapat tiga kilang pemasok LNG di Indonesia, yaitu Badak LNG di Bontang, Kalimantan Timur; Donggi Senoro LNG di Banggai; Sulawesi Tengah; dan Tangguh LNG di Bintuni, Papua Barat. Produksi LNG di setiap kilang akan digunakan untuk pemenuhan kebutuhan gas domestik dan ekspor Indonesia [4] (Gambar 3). Badak LNG memiliki kapasitas produksi hingga 22.500.000 ton per tahun, sedangkan Donggi Senoro dan Tangguh LNG memiliki tingkat produksi sebesar 335.000.000 dan 925.000.000 feet $^{3}$ LNG per hari. Harga LNG di kilang Badak, Donggi Senoro, dan Tangguh LNG secara berurutan yaitu $\$ 5, \$ 6,5$, dan $\$ 6,5$ per MBTU. Semua kilang dapat melayani kapal pengangkut gas dengan kapasitas muat hingga $150.000 \mathrm{~m}^{3}$.

\section{Unit Pembangkitan Listrik Tenaga Gas di Jawa}

Terdapat lima Unit Pembagkitan (UP) Listrik Tenaga Gas yang dituju untuk dipasok gas alam, yaitu UP Muara Karang di Jakarta, Muara Tawar di Bekasi, Gresik di Jawa Timur, Grati di Pasuruan, dan Jawa 1 di Karawang, Jawa Barat. Jumlah UP dan kapasitas daya total tersebut berbeda dengan kondisi saat ini, karena terdapat pembangunan UP baru, yaitu Jawa 1 dan peningkatan kapasitas daya pada UP Grati. (Gambar 4)

Terdapat tiga jenis mesin pembangkit listrik tenaga gas, yaitu turbin gas, turbin uap, dan mesin dengan siklus gabungan (combined cycle). Unit Pembangkitan dengan kapasitas daya terbesar adalah UP Gresik, dengan kapasitas daya total sebesar 2219 MW, sedangkan yang terkecil adalah UP Muara Karang dengan kapasitas total 909 MW. Kapasitas daya total Unit Pembangkitan Listrik Tenaga Gas di Pulau Jawa sebesar 8.246 MW.

\section{E. Distribusi LNG di Pulau Jawa Saat Ini}

Terdapat empat PLTG yang akan dipasok gas alam, yaitu UP Muara Karang, Muara Tawar, Gresik, dan Grati. Kebutuhan

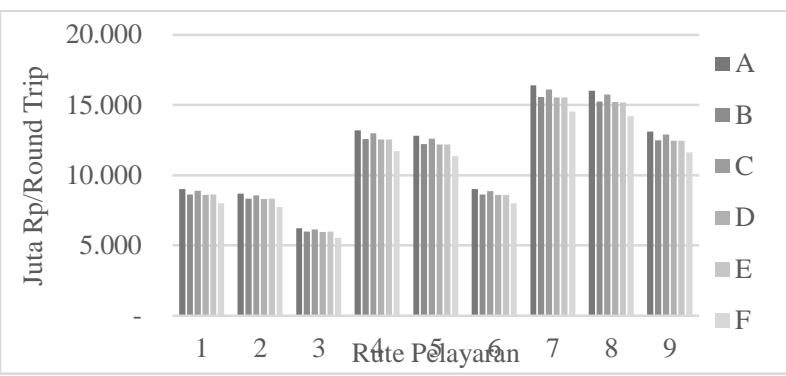

Gambar 10. Biaya BBM Setiap Kapal.

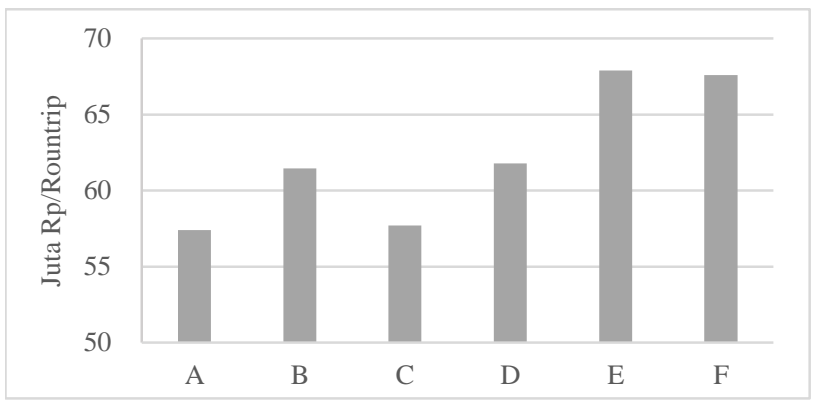

Gambar 11. Biaya Kepelabuhanan Setiap Kapal.

akan bahan bakar gas di Muara Karang dan Muara Tawar dipasok dari Kilang Badak LNG dengan menggunakan kapal pengangkut LNG, karena di Teluk Jakarta terdapat terminal regasifikasi yang berjenis FSRU. FSRU Jawa Barat tersebut menjadi terminal penerima sekaligus fasilitas regasifikasi yang merubah LNG menjadi bentuk gas. Gas alam tersebut digunakan sebagai bahan bakar pembangkit listrik dan dialirkan menuju UP Muara Tawar dengan menggunakan jaringan pipa gas. Sedangkan kebutuhan akan bahan bakar gas di UP. Gresik dan Grati dipasok dari kilang gas yang terdapat di Blok Kangean PSC. Gas dari Blok Kangean PSC dialirkan melalui jaringan pipa bawah laut dari Kangean menuju Grati dan jaringan pipa darat dari Grati menuju Gresik [5]. (Gambar 5)

\section{ANALISIS DAN PEMBAHASAN}

\section{A. Analisis Pasokan LNG}

Analisis pasokan LNG dilakukan untuk mengetahui jumlah pasokan LNG yang digunakan untuk memenuhi permintaan pada masing-masing tujuan. Persentase pemenuhan gas domestik tersebut yang memepengaruhi jumlah produksi LNG yang digunakan sebagai pasokan untuk masing-masing pembangkit listrik. (Gambar 6)

Proyeksi pemenuhan kebutuhan gas domestik dan ekspor Indonesia dilakukan hingga tahun 2025. Pemenuhan gas domestik selalu meningkat dan jumlah gas yang diekspor menurun. Persentase jumlah gas yang digunakan untuk memenuhi kebutuhan gas domestik pada 2025 sebesar $68 \%$ dari jumlah produksi gas total di Indonesia. Hal tersebut menunjukkan bahwa hingga tahun 2025 pemenuhan kebutuhan gas domestik adalah prioritas utama bila dibandingkan dengan ekspor gas ke luar negeri. Berdasarkan hasil ramalan tersebut, jumlah pasokan gas yang digunakan untuk memenuhi kebutuhan gas domestik sebesar $68 \%$ dari produksi gas total. Pasokan LNG untuk Pulau Jawa sebesar $75 \%$ dari jumlah pasokan gas yang digunakan untuk memenuhi kebutuhan gas domestik. (Gambar 7) 


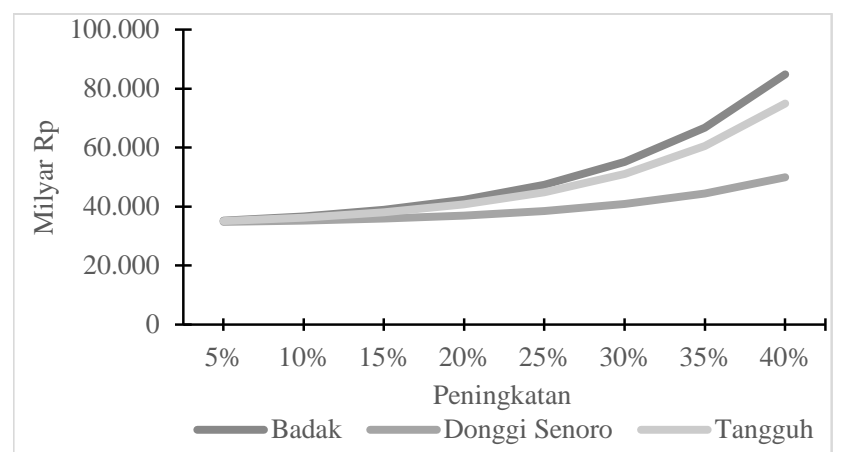

Gambar 12. Hasil Analisis Sensitivitas Biaya LNG.

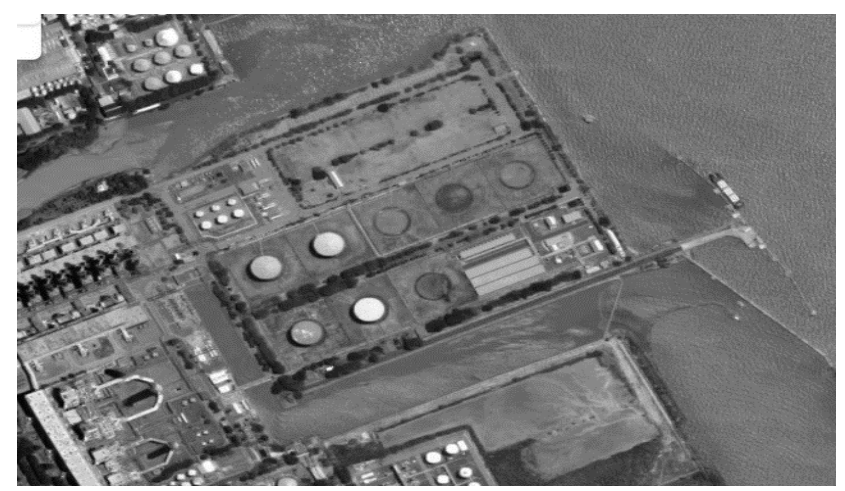

Gambar 13. Lokasi Perencanaan Terminal Regasifikasi.

Jumlah produksi tersebut berdasarkan persentase alokasi jumlah produksi LNG di masing-masing kilang yang telah dianalisis. Produksi Badak LNG memiliki jumlah LNG terbesar yang digunakan untuk memenuhi kebutuhan domestik di Pulau Jawa, yaitu 4.588.445 ton/tahun, sedangkan jumlah terkecil adalah yang berasal dari kilang Donggi Senoro LNG, yaitu 1.280.345 ton/tahun.

\section{B. Analisis Permintaan $L N G$}

Permintaan LNG adalah jumlah kebutuhan akan gas alam oleh pembangkit listrik sebagai bahan bakar untuk menggerakkan mesin turbin yang akan menghasilkan tenaga listrik. Kebutuhan akan LNG tersebut berdasarkan konsumsi gas oleh mesin pembangkit (heat rate) dengan daya masingmasing. (Gambar 8)

Kebutuhan total dari semua Unit Pembangkitan adalah 8.626.631 ton/tahun. Unit Pembangkitan dengan kebutuhan gas terbesar adalah UP Muara Karang, yaitu sebesar 2.794.678 ton/tahun.

\section{Optimisasi Distribusi LNG di Pulau Jawa}

Terdapat tiga kilang produksi LNG yang akan memasok PLTG di Pulau Jawa, yaitu Badak LNG di Bontang, Kalimantan Timur, Donggi Senoro LNG di Banggai, Sulawesi Tengah, dan Tangguh LNG di Bintuni, Papua Barat. Sedangkan PLTG di Pulau Jawa yang dipasok gas alam berjumlah lima unit pembangkitan, yaitu UP Muara Karang di Jakarta, Muara Tawar di Bekasi, Jawa 1 di Karawang, Jawa Barat serta Gresik dan Grati yang terletak di Gresik dan Pasuruan, Jawa Timur. Terdapat rute distribusi LNG dari kilang asal menuju PLTG yang terdapat di Pulau Jawa, baik rute untuk transportasi laut, maupun transportasi darat. (Tabel 1)
Tabel 4.

Perhitungan Fasilitas Perairan Terminal Regasifikasi

\begin{tabular}{lll}
\hline \hline Fasilitas & & Ukuran $(\mathrm{m})$ \\
\hline Kedalaman & Laut terbuka & 12 \\
& Alur masuk & 11,5 \\
\multirow{3}{*}{ Alur } & Kolam dermaga & 11 \\
& Lebar & 420 \\
Kolam putar & Panjang & 5.040 \\
Kolam dermaga & dengan Pandu & 560 \\
& Panjang & 350 \\
& Lebar & 54 \\
\hline \hline
\end{tabular}

Tabel 5 .

Hasil Perhitungan Biaya Fasilitas Darat Terminal

\begin{tabular}{lr}
\hline Komponen & Biaya (Rp) \\
\hline Renovasi jetty & 27.817 .404 .300 \\
Biaya tangki timbun & 3.164 .175 .001 .406 \\
Biaya unloading arm & 60.705 .963 .045 \\
Biaya gas pipe line & 3.515 .750 .000 \\
Biaya cryogenic pipeline & 11.601 .975 .000 \\
Biaya marine pump & 1.012 .536 .000 \\
Regasifier & 421.890 .000 \\
Boil-off gas compressor & 421.890 .000 \\
High pressure pump & 703.150 .000 \\
ORV & 239.071 .000 .000 \\
Total & 3.509 .446 .559 .751 \\
\hline
\end{tabular}

Setelah mengetahui skema distribusi LNG di Pulau Jawa, dilakukan perhitungan biaya transportasi laut. Terdapat enam alternatif kapal yang akan digunakan dalam distribusi. (Tabel 2)

Berdasarkan alternatif kapal dan rute pelayaran yang didapatkan, dihitung biaya bahan bakar dan kepelabuahan kapal. (Gambar 10)

Biaya BBM tertinggi terdapat pada rute yang berasal dari Tangguh LNG, sedangkan yang terendah terdapat pada rute yang berasal dari Badak LNG. (Gambar 11)

Tarif kepelabuhanan di setiap kilang asal dan terminal penerima diasumsikan sama, sehingga hal yang memengaruhi biaya kepelabuhanan adalah GT kapal. Kapal dengan GT terbesar memiliki biaya kepelabuhanan terbesar, yaitu kapal E.

Analisis selanjutnya yang dilakukan adalah melakukan perhitungan biaya total distribusi LNG di Pulau Jawa berdasarkan model optimisasi yang telah dirumuskan secara matematis. (Tabel 3)

Hasil biaya total minum yang didapatkan adalah terpilihnya 4 kapal untuk mendistribusikan LNG dari kilang produksi menuju PLTG di Jawa. Kapal tersebut adalah kapal B, C, D, dan $\mathrm{F}$ yang mengirimkan $16.244 .803 \mathrm{~m}^{3} \mathrm{LNG}$ dengan total biaya sebesar Rp34.620.155.621.573 dan biaya satuan LNG sebesar \$7,53/MBTU. Nilai 14,5\% ICP sebesar \$9,75 [6], sehingga biaya satuan yang diperoleh dari model optimisasi lebih rendah dari nilai tersebut.

\section{Analisis Sensitivitas}

Analisis sensitivitas bertujuan untuk mengetahui dampak yang akan terjadi dengan hasil analisis apabila terdapat perubahan pada dasar-dasar perhitungan biaya. Analisis mengenai peningkatan biaya LNG di setiap kilang produksi terhadap biaya total distribusi LNG di Pulau Jawa. (Gambar 12)

Terdapat tiga kilang produksi yang menjadi pemasok LNG, yaitu Badak LNG, Donggi Senoro LNG, dan Tangguh LNG dengan masing-masing biaya LNG di kilang senilai $\$ 5,5, \$ 6$, dan $\$ 6,5$ per MBTU. Analisis sensitivitas tersebut dilakukan 
Tabel 6.

Hasil Perhitungan Biaya Operasi Terminal Regasifikasi

\begin{tabular}{lrr}
\hline \hline Kenaikan biaya & \multicolumn{1}{l}{$5 \%$ tahun } & 25 \\
\hline Tahun Ke- & 1 & Rp/Tahun \\
Biaya Operasional & Rp/Tahun & 16.537 .500 .000 \\
Gaji Pekerja & 15.750 .000 .000 & 236.486 .250 \\
Biaya listrik & 225.225 .000 & 73.698 .377 .755 \\
R \& M & 70.188 .931 .195 & 36.849 .188 .877 \\
Asuransi & 35.094 .465 .598 & 2.546 .431 .058 \\
Biaya umum & 2.425 .172 .436 & 129.867 .983 .940 \\
Total & 123.683 .794 .228 & 8.543 .393 .580 \\
Present Value & 110.927 .169 .712 & \\
\hline \hline
\end{tabular}

untuk mengetahui dampak dari peningkatan biaya LNG di setiap kilang sebesar $5-40 \%$ terhadap biaya total distribusi LNG di Pulau Jawa. peningkatan biaya LNG di kilang Badak LNG memiliki pengaruh terbesar terhadap biaya total distribusi LNG, karena muatan terangkut yang berasal dari kilang Badak LNG memiliki jumlah terbesar dalam distribusi LNG, meskipun biaya LNG tersebut adalah yang terendah. Peningkatan sebesar $15 \%$ menjadikan pengaruh dari Badak dan Tangguh LNG memiliki perbedaan yang kecil. Peningkatan biaya pada Donggi Senoro LNG tidak memiliki pengaruh yang besar terhadap biaya total distribusi.

\section{E. Perencanaan Terminal Regasifikasi}

Perencanaan terminal regasifikasi dilakukan berdasarkan perhitungan dan hasil dari model optimisasi yang telah dilakukan. Perencanaan dimulai dengan menentukan lokasi yang akan menjadi tempat di mana terminal tersebut akan dibangun. Perencanaan pembangunan terminal regasifikasi berlokasi di Gresik, tepatnya di komplek Unit Pembangkitas Gresik. (Gambar 13)

Lokasi tersebut memiliki lahan yang dapat dibangun terminal regasifikasi kurang lebih seluas $2.500 \mathrm{~m}^{2}$. Berdasarkan lokasi yang ditampilkan tersebut terdapat daerah yang tidak dapat dibangun terminal, dan terdapat jetty untuk tambat kapal. Berdasarkan perhitungan yang dilakukan, didapatkan data kapal terbesar yang tambat, yaitu kapal B dengan panjang 280 $\mathrm{m}$, lebar $43 \mathrm{~m}$, dan sarat $10 \mathrm{~m}$. Perencanaan dilanjutkan dengan melakukan perhitungan fasilitas perairan terminal regasifikasi.

Langkah selanjutnya setelah menentukan lokasi pembangunan adalah merencanakan kapasitas penyimpanan pada terminal regasifikasi. Kapasitas penyimpanan tersebut didapatkan dari pengelolaan muatan yang dikirimkan berdasarkan jadwal kedatangan kapal. Penjadwalan kapal tersebut menghasilkan ukuran kapasitas penyimpanan yang dibutuhkan sebesar $150.000 \mathrm{~m}^{3}$. Berdasarkan volume tangki penyimpanan tersebut, diasumsikan bahwa kapasitas total tangki penyimpanan yang direncanakan sebesar $150.000 \mathrm{~m}^{3}$ dengan dua unit tangki yang masing-masing berkapasitas $75.000 \mathrm{~m} 3$. Asumsi tersebut berdasarkan kondisi distribusi LNG skala kecil hingga menengah yang lebih sesuai menggunakan tangki penyimpanan yang berjumlah lebih dari satu [7], dan mengingat terminal regasifikasi yang direncanakan akan melayani UP Gresik dan Grati yang terdapat di Pasuruan. Perencananaan dilanjutkan dengan perhitungan biaya fasilitas dan operasi terminal. (Tabel 5)

Komponen dengan biaya terbesar adalah biaya tangki penyimpanan sebesar $90 \%$ dari biaya total, yaitu Rp3.164.175.001.406. Biaya total fasilitas terminal regasifikasi

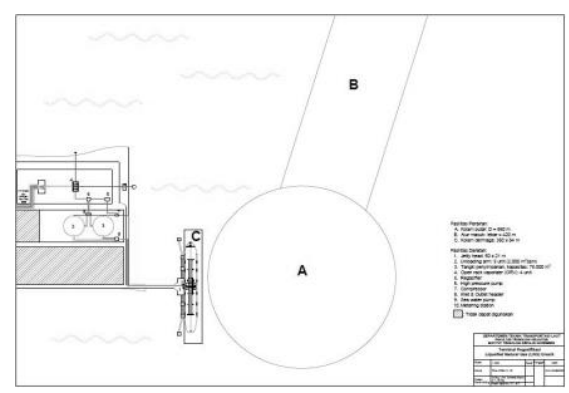

Gambar 14. Layout Perencanaan Terminal Regasifikasi.

Gresik sebesar Rp3.509.446.559.751. Biaya total fasilitas terminal regasifikasi Gresik tersebut digunakan untuk biaya kapital pada perhitungan biaya terminal regasifikasi Gresik. (Tabel 6)

Berdasarkan perhitungan biaya kapital dan operasi terminal, diperoleh biaya per tahun terminal sebesar Rp561.191.198.608 dengan umur ekonomis terminal selama 25 tahun. Perhitungan tersebut berdasarkan penjumlahan biaya kapital dan present value biaya operasi terminal yang kemudian dianuitaskan. Setelah semua perhitungan selesai, dilakukan perencanaan layout terminal regasifikasi. Perencanaan terminal regasifikasi Gresik yang dilakukan menghasilkan rancangan layout terminal regasifikasi. Layout tersebut bertujuan untuk mengetahui bagaimana tata letak fasilitas dan alur proses operasi terminal regasifikasi. (Gambar 14)

Terdapat fasilitas perairan terminal regasifikasi Gresik, yaitu alur pelayaran kapal dengan lebar $420 \mathrm{~m}$, kolam putar dengan diameter $560 \mathrm{~m}$, dan kolam dermaga dengan ukuran 350 x 54 m. Fasilitas darat terminal regasifikasi Gresik, yaitu jetty dengan panjang $300 \mathrm{~m}$ dan jetty heat berukuran $50 \times 21 \mathrm{~m}$, lima unit unloading arm dengan kapasitas $2.000 \mathrm{~m}^{3} / \mathrm{jam}$, dua unit tangki penyimpanan dengan kapasitas $75.000 \mathrm{~m}^{3}$. Empat unit ORV dengan kapasitas 150 ton/jam, satu unit regasifier, high pressure pump, compressor, inlet \& outlet header, sea water pump, dan metering station. Layout tersebut menggambarkan alur bongkar LNG, yang dimulai dengan kapal pengangkut LNG yang memasuki alur masuk dengan menggunakan fasilitas pandu dan tunda, kemudian mengatur posisi tambat di kolam putar lalu tambat pada jetty. Setelah kapal tambat dan melakukan persiapan bongkar, kapal pengangkut LNG melakukan bongkar muatan dengan pompa kapal yang dialirkan dengan menggunakan unloading arm. LNG kemudian dialirkan melalui pipa kriogenik menuju tangki penyimpanan. LNG disimpan di tangki penyimpanan dan apabila terjadi boil-off gas, kompresor akan mengalirkan boil-off gas tersebut kembali ke kapal. LNG dalam tangki penyimpanan kemudian dialirkan oleh high pressure pump menuju vaporizer untuk diubah menjadi bentuk gas. LNG yang telah diregasifikasi pada vaporizer tersebut dialirkan menuju metering station untuk dilakukan pengukuran volume dan tekanan, kemudian dialirkan menuju Unit Pembangkitan Listrik Tenaga Gas [8].

\section{KESIMPULAN/RINGKASAN}

Berdasarkan analisis dan pembahasan yang telah dilakukan pada penelitian ini, didapatkan kesimpulan sebagai berikut:

1. Kondisi distribusi LNG di Pulau Jawa saat ini memiliki 2 (dua) kilang pemasok, yaitu Badak LNG dan Blok Kangean 
PSC serta 4 (empat) Unit Pembangkitan (UP), yaitu Muara Karang, Muara Tawar, Gresik, dan Grati kilang. Badak LNG memasok Muara Karang dengan menggunakan kapal yang kemudian meneruskan distribusi gas alam menuju UP Muara Tawar dengan menggunakan pipa gas. Sedangkan Blok Kangean PSC memasok gas alam menuju UP Gresik dan Grati menggunakan jaringan pipa gas laut dan darat dengan panjang total lebih dari $350 \mathrm{~km}$.

2. Model optimisasi distribusi LNG untuk memasok PLTG di Pulau Jawa menghasilkan pola distribusi dengan menggunakan 4 (empat) kapal terpilih yang masing-masing memiliki kapasitas angkut $130.827 \mathrm{~m}^{3}, 120.304 \mathrm{~m} 3$, $124.686 \mathrm{~m}^{3}$, dan $110.543 \mathrm{~m}^{3}$ serta jaringan pipa darat sepanjang 27 dan $98 \mathrm{~km}$. Volume LNG yang terkirim adalah 16.244.803 $\mathrm{m}^{3}$ LNG dengan biaya total sebesar Rp34.620.155.621.573 dan biaya satuan \$7,53/MBTU.

3. Terminal regasifikasi yang direncanakan memiliki memiliki fasilitas regasifikasi berjenis open rack vaporizer (ORV) dan 2 (dua) unit tangki penyimpanan berkapasitas 75.000 $\mathrm{m}^{3}$ dengan biaya per tahun sebesar Rp561.191.198.608.

\section{UCAPAN TERIMA KASIH}

Penulis mengucapkan terima kasih kepada orang tua dan seluruh keluarga penulis. Selain itu, penulis juga mengucapkan terima kasih untuk FTK Kelautan dan Laboratorium Telematika Transportasi Laut.

\section{DAFTAR PUSTAKA}

[1] P. Budi Santosa, Metode Heuristik, Konsep dan Implementasi. Surabaya: Guna Widya, 2011.

[2] PT. PLN, "Rencana Usaha Penyedia Tenaga Listrik (RUPTL) PLN $2017-$ 2026," Jakarta, 2017.

[3] SKKMIGAS, "Produksi Minyak dan Gas Bumi," Jakarta, 2019.

[4] Soegiono and K. Artana, Transportasi LNG Indonesia. Surabaya: Airlangga University Press, 2006.

[5] M. Giranza, "Techno-Economic Study of Shipping LNG to Indonesia from US, Australia, and Qatar by LNG Carrier," Dundee, 2018.

[6] International Gas Union, "World Gas Energy Report," Washington, 2018.

[7] A. Jackson, Liquefied Natural Gas (LNG) Receiving Terminal and Associated Facilities. Hong Kong: ERM, 2005.

[8] NatGas, "The Transportation of Natural Gas," 2013. [Online]. Available: http://naturalgas.org/naturalgas/transport/. 